\title{
Clinical Audit for Use of Corticosteroids in Treatment of Nervous System Infections
}

\author{
AL-SAYED K.A. KARIM, M.D.; MOSTAFA S. KHALAF, M.D. and DINA K. EZZAT, M.Sc. \\ The Department of Pediatrics, Assiut University Hospital, Assiut, Egypt
}

\begin{abstract}
Background: Anti-inflammatory therapy is indicated for CNS infection. Corticosteroids are the most valuable antiinflammatory drugs for CNS disease. They reduce CNS edema via their action on blood vessels, and they produce antiinflammatory effects via their action on neutrophils and inhibition of cytokine synthesis.
\end{abstract}

Patients and Methods: Retrospective study was conducted on patients admitted to Emergency Unit, intermediate care unit, Pediatric Intensive Care Unit and Department Neurology at Assiut University Children Hospital during the period from January 2016 to December 2016. Data is collected and compared to guidelines.

Results: Corticosteroids was used in $100 \%$ of cases. Most of cases with CNS infection who received steroid treatment guided by treatment protocol showed marked improvement in GCS score, tendon reflexes, muscle tone and convulsions.

Conclusion: Corticosteroids are usually the primary drugs used to treat immune-mediated disorders of the CNS, including corticosteroid-responsive meningitis and corticosteroidresponsive meningomyelitis.

Key Words: Corticosteroids - CNS infections - Brain edema - Anti-inflammatory.

\section{Introduction}

IN general, the Central Nervous System (CNS) is well defended against infection. The spine and brain are sheathed in tough, protective membranes, dura matter, pia matter and arachinoid matter. These defenses are not absolute. In rare cases, bacteria gain access to areas within the CNS [1].

Infections of the CNS can be divided into 2 broad categories; those primarily involving the meninges (meningitis) and those primarily confined to the parenchyma (encephalitis) [2] .

Correspondence to: Dr. Dina K. Ezzat, E-Mail: dinakma190@gmail.com
Infectious organisms can invade the fluid surrounding the brain. The body tries to fight the infection by increasing the number of white blood cells (normally a helpful immune system response), but this can lead to increased inflammation. As the inflammation increases, brain tissue can start swelling and blood flow to vital areas of the brain can decrease. As pus and other material from an infection accumulate in CNS, pressure is exerted on the brain or spinal cord. This pressure can damage the nervous system tissue, possibly permanently. Without treatment; CNS infection is fatal [3].

Adjunctive treatment with steroids for bacterial meningitis was reported in the 1950s in the form of several case reports and a small case series, all of which indicated improved outcomes for patients treated with antibiotics in conjunction with adrenocorticotropic hormone and hydrocortisone compared with patient outcomes in earlier reports of treatment with antibiotics alone [4]. Interestingly, these benefits were not observed if steroid treatment was delayed until 5 days after admission. Bacterial lysis induced by antibiotics causes inflammation in the subarachnoid space, and this response is attenuated by steroid treatment, thereby improving the outcome [5].

The aim of this study is to: Assess how much the adopted protocol of using corticosteroids in management of CNS infections is implemented in Assiut University Children Hospital (A.U.C.H).

\footnotetext{
Abbreviations:

CNS : Central Nervous System.

ADEM : Acute Disseminated Encephalomyelitis.

A.U.C.H : Assiut University Children Hospital.

C.S.F : Cerprospinal Fluid.
} 


\section{Patients and Methods}

Research design: Clinical retrospective audit on use of corticosteroids in treatment of nervous system infections in children at A.U.C.H from January 2016 to December 2016.

\section{Inclusion criteria:}

This clinical audit study included all children with:

- Bacterial meningitis.

- Tuberculous meningitis.

- Acute infectious encephalitis.

- Herpes simplex encephalitis.

- Acute disseminated encephalomyelitis.

\section{Exclusion criteria:}

Children were excluded from this study if they were diagnosed as having:

- Brain tumor.

- Neurodegenerative disorders.

- Congenital cranial malformation.

- Intracranial hemorrhage.

\section{Results}

Our study is clinical retrospective audit on use of corticosteroids in treatment of nervous system infections in children at A.U.C.H from January 2016 to December 2016. The study included 50 patients with CNS infections. 27 cases were male and 23 cases were female. Ninteen cases were below the age of one year, 25 cases between the age of one year and ten years and 5 cases more than ten years old. Data of the study showed that AUCH partially followed the reference standard of the study.

Table (1): Corticosteroids use in bacterial meningitis group.

\begin{tabular}{lcccc}
\hline & \multicolumn{4}{c}{ Bacterial meningitis (n=23) } \\
\cline { 2 - 6 } & \multicolumn{3}{c}{ Yes } & \multicolumn{3}{c}{ No } \\
\cline { 2 - 6 } & No. & $\%$ & No. & $\%$ \\
\hline - Dexamethasone use. & 23 & 100.0 & 0 & 0.0 \\
- Administrated at 15-20min before or & 12 & 52.2 & 11 & 47.8 \\
$\quad$ with the 1st dose of antibiotics. & & & & \\
- Dose: 0.15mg/kg dose q6h. & 10 & 43.5 & 13 & 56.5 \\
- For 2-4 days. & 4 & 17.4 & 19 & 82.6 \\
- Side effects of corticosteroids. & 12 & 52.2 & 11 & 47.8 \\
- Improvement: & & & & \\
$\quad$ GCS & 22 & 95.7 & 1 & 4.3 \\
$\quad$ Muscle tone & 13 & 56.5 & 10 & 43.5 \\
$\quad$ Muscle reflexes & 17 & 73.9 & 6 & 26.1 \\
$\quad$ Convulsions & 14 & 60.9 & 9 & 39.1 \\
\hline
\end{tabular}

Table (2): Corticosteroids use in Tuberculous meningitis.

\begin{tabular}{lcccc}
\hline & \multicolumn{3}{c}{ Tuberculous meningitis (n=3) } \\
\cline { 2 - 5 } & \multicolumn{2}{c}{ Yes } & \multicolumn{2}{c}{ No } \\
\cline { 2 - 5 } & No. & $\%$ & No. & $\%$ \\
\hline - Dexamethasone use. & 3 & 100.0 & 0 & 0.0 \\
- At the time of presentation. & 1 & 33.3 & 2 & 66.7 \\
- Patients with GCS score of less & 1 & 33.3 & 2 & 66.7 \\
than 15 or who have a focal & & & & \\
neurological deficits & & & & \\
administrated steroids as guided & & & & \\
protocol. & & & & \\
- Patients with normal mental status & 1 & 33.3 & 2 & 66.7 \\
$\quad$ and no neurological deficits & & & & \\
administrated steroids as guided & & & & \\
protocol. & & & & \\
- Patients with normal mental status & 1 & 33.3 & 2 & 66.7 \\
$\quad$ and no neurological deficits didn't & & & & \\
administrated steroids as guided & & & & \\
protocol. & & & & \\
- Side effect of corticosteroids. & 3 & 100.0 & 0 & 0.0 \\
- Improvement: & & & & \\
$\quad$ GCS & 0 & 0.0 & 3 & 100.0 \\
$\quad$ Muscle tone & 1 & 33.3 & 2 & 66.7 \\
$\quad$ Muscle reflexes & 0 & 0.0 & 3 & 100.0 \\
$\quad$ Convulsions & 1 & 33.3 & 2 & 66.7 \\
\hline
\end{tabular}

Table (3): Corticosteroids use in encephalitis.

\begin{tabular}{lcccc}
\hline & \multicolumn{4}{c}{ Encephalitis (n=13) } \\
\cline { 2 - 6 } & \multicolumn{2}{c}{ Yes } & \multicolumn{2}{c}{ No } \\
\cline { 2 - 6 } & No. & $\%$ & No. & $\%$ \\
\hline - Dexamethasone use. & 13 & 100.0 & 0 & 0.0 \\
- After 3 days of presentation. & 2 & 15.4 & 11 & 84.6 \\
- Dose: 0.15mg/kg dose q6h. & 4 & 30.8 & 9 & 69.2 \\
- For 3-5 days. & 2 & 15.4 & 11 & 84.6 \\
- Prednisolone use. & 2 & 15.4 & 11 & 84.6 \\
- Dose: 2mg/kg day once. & 2 & 15.4 & 11 & 84.6 \\
- For 3-5 days. & 1 & 7.7 & 12 & 92.3 \\
- Side effects of corticosteroids. & 4 & 30.8 & 9 & 69.2 \\
- Improvement: & & & & \\
$\quad$ GCS & 11 & 84.6 & 2 & 15.4 \\
$\quad$ Muscle tone & 8 & 61.5 & 5 & 38.5 \\
$\quad$ Muscle reflexes & 8 & 61.5 & 5 & 38.5 \\
$\quad$ Convulsions & 8 & 61.5 & 5 & 38.5 \\
\hline
\end{tabular}

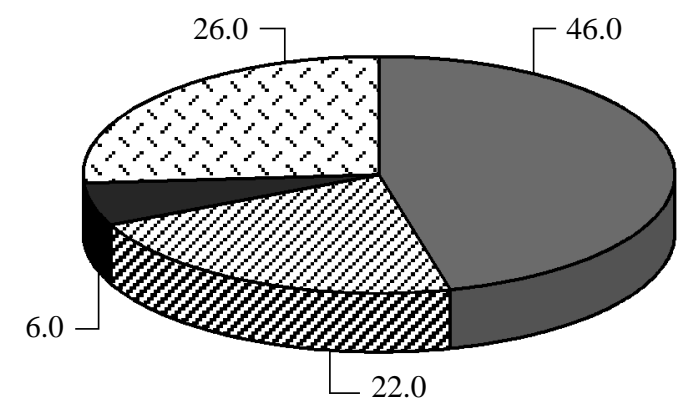

$\begin{array}{ll}\square \text { Bactrial meningitis } & \square \text { Tuberculous meningitis } \\ Q \text { ADEM } & \text { Encephalitis }\end{array}$

Fig. (1): CNS infection type distribution. 


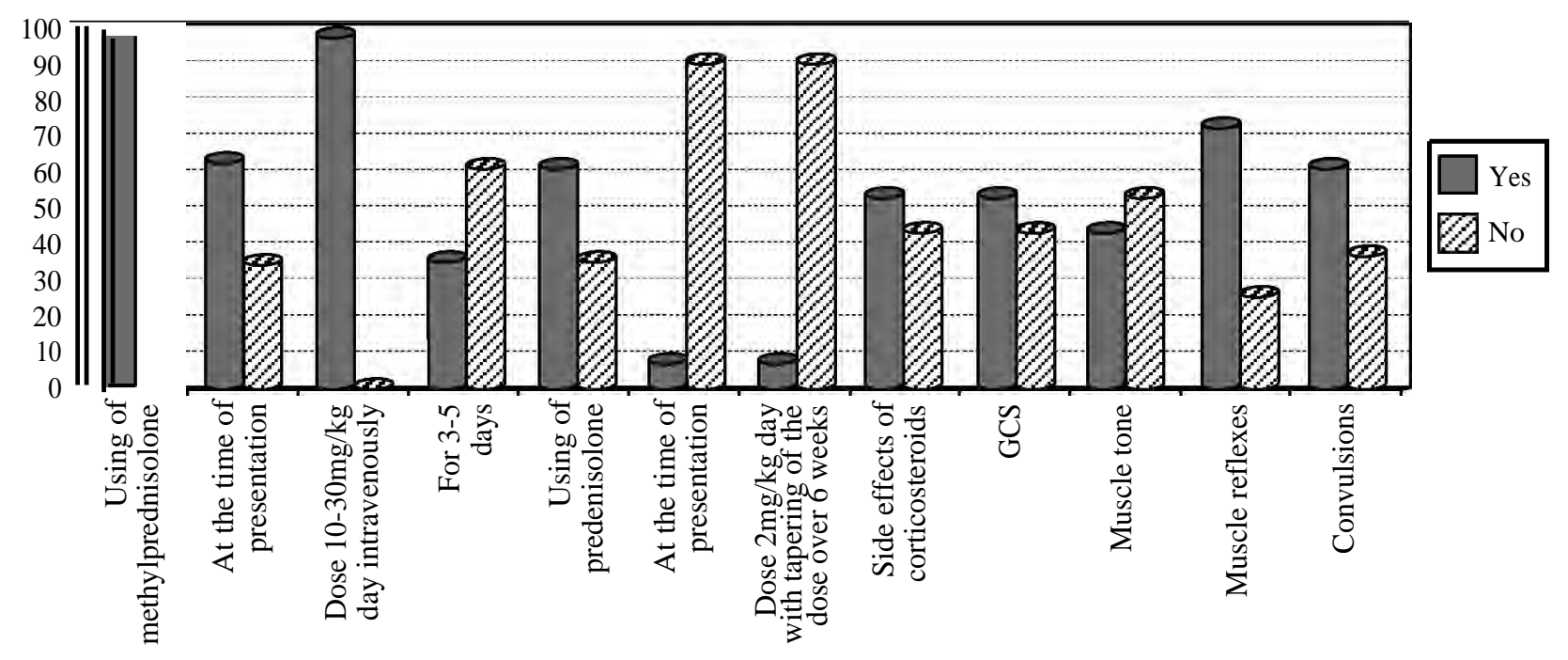

Fig. (2): Corticosteroids use in ADEM group.

\section{Discussion}

According to protocol of corticosteroids treatment during CNS infections at A.U.C.H.

Our study include (50) patients diagnosed as CNS infections at Assiut University Children Hospital. Their age ranged from (1) month to (18) years, 27 cases were male and 23 cases were female.

A full history and detailed clinical (general, systemic and neurological) examination must be done for all cases of suspected CNS infection (full history was taken from $98 \%$ of cases, but full examination was done for $90 \%$ of cases).

Laboratory investigations (e.g. CBC, CRP, ESR, serum $\mathrm{Na}, \mathrm{K}, \mathrm{ca}, \mathrm{Mg}, \mathrm{BUN}$, serum creatinine, blood culture and CSF taping for analysis, culture and sensitivity test and serology for viral infection must be done for all cases of suspected CNS infection in children (in our study all those investigations were done in only $36 \%$ of cases, CSF analysis was done for all cases).

Corticosteroids must be administrated as adjunctive therapy for all cases of CNS infection in children (in our study all cases were treated with corticosteroids).

Corticosteroid therapy must be started at appropriate time as adjunctive therapy according to the type of CNS infection (in our study, only $76 \%$ of cases started corticosteroids at appropriate time).

Corticosteroids must be given in appropriate doses and route according to the adapted protocol of corticosteroid use in management of CNS infection in children (in our study $57 \%$ of cases administrated corticosteroids in appropriate doses, but $95 \%$ of cases administrated it in appropriate rout).

Corticosteroids must be given for appropriate duration according to the type of CNS infection and following the treatment guidelines provided (in our study $88 \%$ of cases administrated corticosteroids for appropriate duration).

Each case treated with corticosteroids must be observed during and after treatment for any steroids side effects and treat it (in our study $27 \%$ of cases suffered from corticosteroids side effects such as gastritis)

Meticulous and long term clinical follow-up of all cases of CNS infection treated with corticosteroids for development of any symptoms of complications and neuroimaging follow-up study may be indicated (in our study, regular long term followup was done for only $47 \%$ of cases).

\section{References}

1- SCHUCHAT A., SORRELL T.C., ALLWORTH A.M., et al.: Bacterial meningitis in the United States in 2014. Active Surveillance Team. N. Engl. J. Med., 337: 970-6, 2014.

2- PEREZ-VELEZ C.M., ANDERSON M.S., ROBINSON C.C., et al.: Outbreak of neurologic enterovirus type 71 disease: A diagnostic challenge. Clin. Infect. Dis., 45 (8): 950-7, 2007.

3- WEISFELT M., CASTELLO M., WONG H.F., et al.: Dexamethasone and longterm outcome in pediatrics with bacterial meningitis. Ann. Neurol., 60: 456-68, 2016.

4- VERNER J.V., JIAN J.W., LIN T.L., et al.: Pneumococcal meningitis treated with hydrocortisone, $\mathrm{ACTH}$, and antibiotics. Univ. Michigan. Med. Bull., 22: 329-40, 2010.

5- HOH T.K. and MONG C.T.: The treatment of purulent meningitis with adrenal cortico-steroids. Singapore Med. J., 3: 73-7, 2012. 


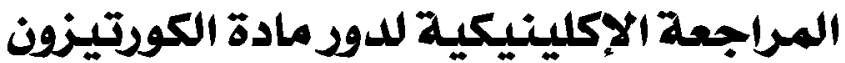

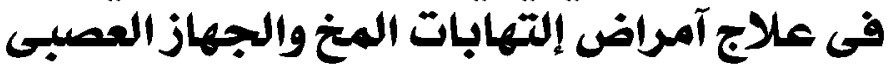

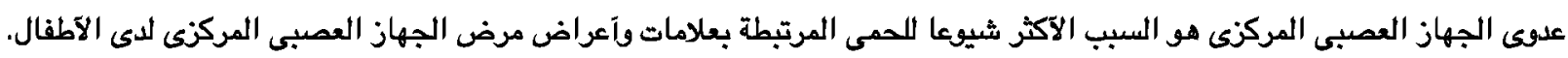

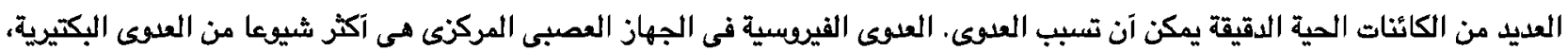
والتى بدورها، هى آكثر شيوعا من العدوى الفطرية والطفيلية.

الهذف من هذه الدراسة المراجعة الإكلينيكية بآثر رجعى هو تقييم مدى تطبيق بوتوكول إستخدام الكوتيكوستيرويدات فى علاج عدوى

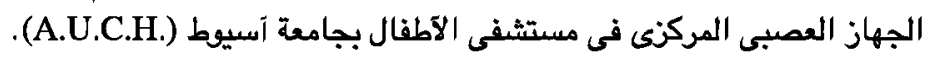

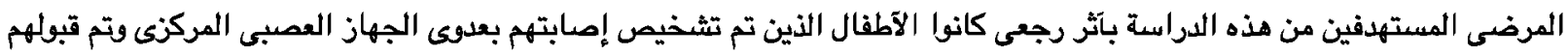

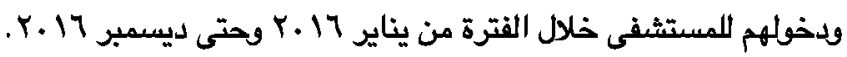

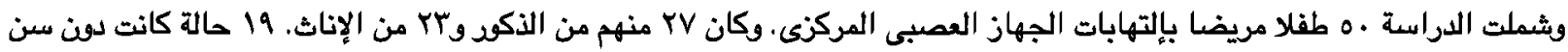

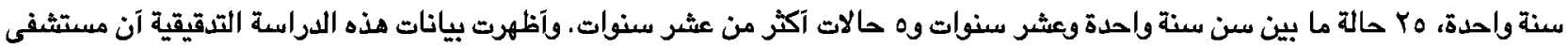

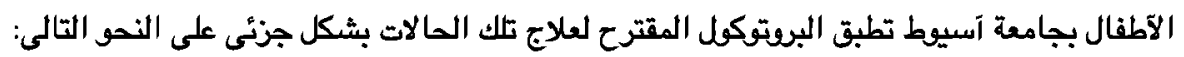
ا- معظم الحالات التى تلقت العلاج بالستيرويد الوجهة بالبروتوكل آظهرت تحسنا ملحوظا إما فى درجة الوعى، إنعكاسات العضلاتي، كفائة

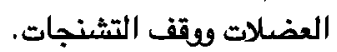

وقد آظهرت هذه الدراسة الإكلينيكية العرجعية الحالية آن مستثفى آسيوط الجامعى للآطفال يطبق جزئيا البروتوكول على النحو التالى:

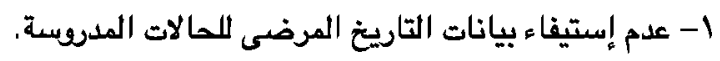

Y- عدم إستيفاء عمل فحص بدنى وعصبى وتسجيل الييانات بشكل كامل ومرتب فى عدد محلود من الحالات.

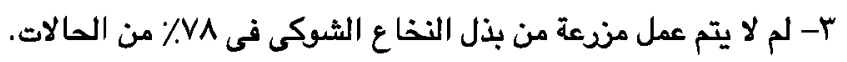

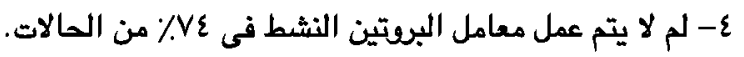

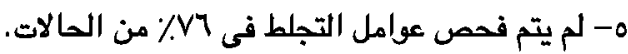

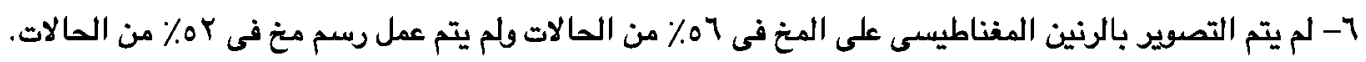
V بروتوكل العلاج بإستخدام الكوتيزونات فى حالات عدوى الجهاز العصبى المركزى لا يطبق بصورة كاهلة. 